\title{
Miranda
}

Revue pluridisciplinaire du monde anglophone /

Multidisciplinary peer-reviewed journal on the English-

speaking world

23 | 2021

Modernist Exceptions

\section{An Exceptional Man? Kurtz and fascination with colonialism, from Conrad to Coppola}

\section{Naomi Toth}

\section{OpenEdition}

\section{Journals}

Electronic version

URL: https://journals.openedition.org/miranda/42610

DOI: 10.4000/miranda.42610

ISSN: 2108-6559

Publisher

Université Toulouse - Jean Jaurès

\section{Electronic reference}

Naomi Toth, "An Exceptional Man? Kurtz and fascination with colonialism, from Conrad to Coppola",

Miranda [Online], 23 | 2021, Online since 12 October 2021, connection on 29 November 2021. URL:

http://journals.openedition.org/miranda/42610 ; DOI: https://doi.org/10.4000/miranda.42610

This text was automatically generated on 29 November 2021.

\section{c.) (i) (2)}

Miranda is licensed under a Creative Commons Attribution-NonCommercial-NoDerivatives 4.0 International License. 


\title{
An Exceptional Man? Kurtz and fascination with colonialism, from Conrad to Coppola
}

\author{
Naomi Toth
}

1 The exceptionally bad, like the exceptionally good, fascinate. And the fascinated, like rabbits immobile before the headlights of oncoming cars, frequently find themselves blinded to the concrete realities of a situation, unable to take the distance necessary to see what is actually at stake, and incapable of adopting an appropriate reaction. Joseph Conrad's 1899 novella "Heart of Darkness" has much to teach us about the fascination with the horrors generated by the colonial enterprise. The novella relates Captain Marlow's journey upriver into Africa on behalf of a colonial Company, in search of one of its agents, Kurtz, who has apparently gone mad. In the eyes of the main narrator Marlow and the other Company employees, Kurtz is an exceptional figure: after excelling in the colonial enterprise in an outstanding way, he becomes its extraordinarily horrific incarnation. However, granting Kurtz such an exceptional status participates in the creation of fascination with the colonial enterprise itself, both on the part of the narrator Marlow and for the reader. If we may nonetheless read Conrad's text as a critique of colonialism, it is on the condition that we remain attentive to the text's narrative strategies which undermine Kurtz's exceptionalism, in other words, which banalize Kurtz.

2 At least since Hannah Arendt coined the term "the banality of evil" in her report on the trail of Adolf Eichmann for his role in the Holocaust, we have been invited to be wary of our fascination with those who perpetrate horrific crimes, of the dangers of according them exceptional status, of setting them apart in a quasi-metaphysical category that exaggerates their talents, intelligence, and monstrosity. Only when we recognize that such perpetrators are human, all too human, Arendt argues, may we begin to identify and analyze with any degree of precision the factors at play in the realization of such horrors. Acknowledging the banal nature of perpetrators is not, however, to set them up as a template for humanity; it is not, in other words, to argue that if perpetrators 
are ordinary human beings, we other ordinary human beings are all potentially monsters and, if the circumstances allowed, we would all commit atrocities. Above all, it is not to banalize the atrocities themselves. Charlotte Lacoste has lucidly exposed and argued against such a skewing of Arendt's position which conveniently lets perpetrators off the hook, and fails to ask the important question of why other Germans acted differently. For ordinary people do, in fact, act differently in the vast majority of cases, refusing to participate in horrific acts (Rechtman). ${ }^{1}$ To banalize perpetrators is, however, to diffuse the smokescreen of fascination and attendant admiration generated when we attribute them an exceptional nature. It is therefore a step towards seeing their acts, about which there is nothing banal, for what they are.

3 To draw out the lessons Conrad's text has to teach us about the fascination of colonialism, however, we must not only engage in a reading which, taking its cues from Arendt and Lacoste, is attentive to the textual strategies that underline the ordinariness of Kurtz the man. We must also go beyond this and remain alert to the signs Conrad gives us that question the exceptional badness of his acts themselves. For Conrad gives us reason to believe that Kurtz is no Eichmann, so that what appears horrific about his acts to his colonial observers might, from a non-colonial perspective, be less shocking, or perhaps even not shocking at all. This allows us to better identify what ideological positions are actually at stake in Marlow's aggrandizement of Kurtz's success and his disaster, and prepare the ground for a more scathing exposition, and critique, of the colonial mindset.

4 Conrad's text may therefore be approached as a thorough-going work of deflation, furnishing the attentive reader with the tools to pick apart the fascination with colonial power it nonetheless so effectively sets up. The critical potential of Conrad's text becomes all the more apparent when compared with Francis Ford Coppola's reprisal of the figure of Kurtz in the film Apocalypse Now (1979). For by exacerbating Kurtz's exceptional nature, the film does not disarm but rather reignites fascination with the colonial enterprise and the exercise of absolute power once again, to questionable ethical ends.

\section{Conrad and colonialism: a vexed question}

"Heart of Darkness" is a notoriously ambiguous text which has lent itself to a plethora of contradictory and often incompatible interpretations. This ambiguity is built into the text's structure, with its multilayered frame narration: Kurtz's story is pieced together by Marlow, Marlow's story is told to the men on board the Nellie on the Thames; the frame narrator's story is then told to the readers. Each layer introduces a margin of error, a potential twisting or tampering with the narrative. As if that were not enough, the reader has reason to believe that none of the three narrators involved is entirely reliable: by his own avowal, Marlow has an ambiguous relationship to truth telling, lying by omission at some points in the tale, actively lying to Kurtz's fiancée in the final pages, and yet describing himself as a hater of lies and as faithful to Kurtz's memory. Not only that, but Marlow's own discourse is far from straightforward, with his long sentences, negative definitions, approximative descriptions, and notorious emphasis on obscurity and mystery. ${ }^{2}$ As for the frame narrator, though he is never described in the text, the opening sequence betrays the fact that he holds Marlow at a suspicious distance, and identifies rather with the others on board the Nellie, those 
listening to Marlow's tale. ${ }^{3}$ The narrative structure therefore inscribes not only irony but also uncertainty and ambiguity in all levels of the text, so much so that many have read it as being primarily about the pitfalls of story-telling and story-reading itselfPeter Brook's discussion of the tale as an "unreadable report" being perhaps the bestknown. ${ }^{4}$

6 It is not then surprising that the text has given rise to innumerable, often contradictory interpretations as to its position on colonization, which forms the context and informs the subject matter of the entire tale. A significant part of the critical literature skirts the question by minimizing the importance of the colonial context or presenting it as primarily metaphorical-or, to use J. Hillis Miller's term, parabolical (Miller 206)-, preferring to read the text as being less about colonialism than about an inner journey into the self (Guerard, or see, as a more recent example amongst many others, Alvarez Calleja); as a critique of civilization (see Trilling); about an engagement with death and truth (Miller 214-215) or the limits of humanity (Pedot 2003, Atkinson), or about a confrontation with an unspeakable "Real" beyond language or the abysses of human desire (see, amongst others, Paccaud-Huguet). ${ }^{5}$ For those who tackle the question directly, criticism can be divided into three broad categories.

7 The first of these sees the text as clearly anti-colonial. This reading emphasizes the ghastly portrait Marlow paints of empire as nothing more than greedy, self-serving exploitation, involving both obvious individual and insidious structural violence, the inhuman treatment of other human beings and senseless, irrational destruction. In this view, any concessions Marlow makes to colonialism in the text should be understood either as part of his attachment to a Romantic vision of exploration and discovery (this is notably the case in Benita Parry's Conrad and Imperialism), or as part of a strategy to make his anti-colonial discourse audible to contemporary readers, explicitly inscribed in the text as listeners to Marlow's tale in the form of the four men on board the boat on the Thames. Indeed, these men, who have spent their career happily and unquestioningly engaged in the colonial enterprise may be seen as figures of contemporary readers, all the more so as the novella was first published in serialized form in Blackwood's magazine. Blackwood's caters primarily to the "middle-class Englishman, officers in the forces or civil servants in the empire" as Batchelor has pointed out (cited in Schaffer, 69). Conrad himself wrote "There isn't a single club and messroom and man-of-war in the British Seas and Dominions which hasn't its copy" (cited in Watt 1979, 100). This school of criticism also frequently underlines the fact that Marlow's voice is not the narrator's, allowing for doubt and irony, meaning that though Marlow's relationship to colonialism may be ambiguous, the subtle reader will be capable of understanding that the overall effect of the text, of its twists and turns and retrospective denunciations of Kurtz, is to expose and critique colonialism's violence rather than participate in it.

On the other end of the scale, we have Chinua Achebe's 1975 Second Chancellors' Lecture at the University of Massachusetts Amherst, subsequently published in the Massachusetts Review, where he showed how Conrad's depiction of Africa and Africans depended on colonial clichés, and famously accused Conrad of being "a thorough-going racist" (Achebe 21). Though Achebe's reading fails notably to account for the frame narration structure and ignores the role certain images play in a critique of civilization that traverses racial lines ${ }^{6}$, his article is significant as one of the first to highlight the 
extent to which Conrad's text is saturated with the racist discourses and representations that aided and abetted colonialism.

Between these two positions lies a third, perhaps best represented by Edward Saïd who, in his chapter dedicated to "Heart of Darkness" in Culture and Imperialism (1993), argues that while Conrad's text is structured by colonial discourse, it nonetheless maintains a critical awareness of this fact. Saïd's Conrad is conscious of the historically contingent nature of the colonial situation and sufficiently detached from it to see both its effective and symbolic violence, while remaining tragically unable to step beyond its representational framework. Indeed, it is now common to teach the text as a historically situated example of how colonialism operated at the time, both in the minds of its defenders and its critics, though the critique it provides falls short of challenging its underlying structures. ${ }^{7}$

Focusing on exceptionalism and the attendant fascination it exerts in this tale both confirms and complements the position Saïd develops. It confirms the fact that colonial imaginaries dominate the text, but also suggests that a critique of colonialism may be found not only in its depiction of colonial violence, but also in the way it lays bare certain fantasies that inform the colonial enterprise.

\section{Constructing Kurtz as exceptional}

11 In the eyes of the colonists in Marlow's tale, Kurtz begins life as an exceptional colonial agent, according to two understandings of the term "exceptional": that of an extreme example within a given category, and that of being categorically different from a dominant norm (OED). Firstly, Kurtz is an exceptional colonist in that he is extremely good at achieving colonialism's material aims, that is, in exploiting African resources on behalf of the Company: indeed the Company's chief accountant, after informing Marlow that Mr. Kurtz is "a remarkable person", explains that he "sends in as much ivory as all the other agents put together." (Conrad 120) ${ }^{8}$ Secondly, he is exempt from the category of ordinary, run-of-the-mill imperialists and the moral judgement one might deliver on them, because he is animated not by greed but by what Marlow describes as a "redeeming idea": the civilizing mission. For Marlow distinguishes between two forms of imperialism in the opening pages of the text, the colonists and the conquerors, using the example of the Roman conquest of Britain:

They [the Romans] were no colonists; their administration was merely a squeeze and nothing more, I suspect. They were conquerors, and for that you want only brute force-nothing to boast of, when you have it, since your strength is just an accident arising from the weakness of others. They grabbed what they could get for the sake of what was to be got. It was just robbery with violence, aggravated murder on a great scale, and men going at it blind-as is very proper for those who tackle a darkness. The conquest of the earth, which mostly means the taking it away from those who have a different complexion or slightly flatter noses than ourselves, it's not a pretty thing when you look into it too much. What redeems it is the idea only. An idea at the back of it; not a sentimental pretense but an idea; and an unselfish belief in the idea-something you can set up, and bow down before, and offer a sacrifice to... (Conrad 107, my emphasis).

12 At the beginning of his career at least, Kurtz definitely believes in such an idea. His fellow colonists talk of him as an "emissary of pity, and science, and progress", as belonging to the "new gang" of Company employees, the "gang of virtue" (Conrad 127), 
and we learn he has been commissioned to write a report for the "International Society for the Suppression of Savage Customs", which critics agree is loosely based on two Belgian colonial organisations, the Association Internationale pour l'Exploration et la Civilisation en Afrique presided by the Belgian King Leopold, and La Société Antiesclavagiste de Belgique. (Conrad 214). He is said to possess great oratory gifts, to be a particularly eloquent defender and disseminator of his ideals. This seems to put him in the category of those redeemed by their belief in the civilizing mission. However, the rhetorical strategies Marlow employs in this passage, particularly the religious imagery used, also allow us to read his discourse not as a defense of the "idea" supposedly animating European colonization, but rather as a denunciation of the guilty complicity of ideology in masking the concrete reality of imperial relations. Thus the apparent distinction between colonialist and conqueror falls apart, and the supposedly exceptional nature of contemporary European colonization versus previous imperial projects appears as convenient myth, blinding practitioners from recognition of the reality of the situation. This passage therefore seems to support an anti-colonialist reading of Marlow's discourse.

Be that as it may, Kurtz remains a revered figure in the text, considered as exceptional by his fellow colonists, who regard him with admiration mixed with envy, or adulation mingled with fear. And in spite of his apparent critique of the colonial ideology of the "civilizing mission", in spite of his attempt to resist the attraction of colonialism, Marlow also clearly considers Kurtz to be exceptional, constantly emphasizing his "remarkable" nature, and his whole narrative, structured as it is around the quest for Kurtz, reproduces his somewhat reluctant but nonetheless overwhelming fascination with the figure. But after having begun his career as a beacon of idealistic colonialism, Kurtz is said to have become an exceptionally horrific demonstration of its brute violence, hence the mission upriver to retrieve him. The vision of Kurtz's Inner Station and, subsequently, of his physical person, strikes immense terror in Marlow-a terror he describes at great length. The Manager puts down what they find there to "unsound methods"; Marlow sees "no method at all", and considers Kurtz to have gone quite simply mad, having lost all restraint-that watchword for Marlow-and given free rein to his appetites for power, women and ivory (Conrad 169). Kurtz, Marlow believes, has turned his immense talent over to the powers of darkness, the "inscrutable wilderness" having hollowed him out and taken over his body, mind and soul (Conrad 164-165). Adhering to Marlow's position, many critics of the first school aforementioned see in Kurtz's destiny the extreme development of the colonial project, in which the will for absolute power and deathly destruction advances barefaced, stripped of any ideological justification, be it the idealistic civilizing discourse of the younger Kurtz or the hypocritical legalism of the manager of the Central station. And if Kurtz the shining example has now become the monstrous incarnation of absolute colonial power, he is no less fascinating for it. Indeed, he becomes Marlow's "choice of nightmares" (Conrad $169,172)$, over that other nightmare, the hypocritical, corrupt and indiscriminately violent colonialism of the other pilgrims.

In reproducing Marlow's vision of Kurtz as exceptionally bad, these critics relay the horror of unbridled power and domination which so easily, as Arendt and Lacoste have shown, encourages or mutates into fascination. It also reproduces a vision of colonialism as a potentially totalizing system, a vision which excludes resistance, exchange, or change. This often prevents these critics-as it prevents Marlow-from 
identifying what is really at stake in the hyperbolic reactions he and the other employees of the colonial Company have to Kurtz's fate, and therefore from remaining sensitive to the textual elements that might allow us to sketch out a more profound critique of colonialism in Conrad's text.

\section{Kurtz's transgression}

15 For when the reader sifts through paragraph upon paragraph evoking the fear, terror and horror Marlow feels about Kurtz, he or she is hard pressed to find concrete details that support the claims of Kurtz's madness, of his rapacious appetites or even of his exercise of excessive, gratuitous violence. There is, of course, the testimony of the Russian Marlow meets, who treats Kurtz as if he were a god to be worshipped and feared, however his testimony is far from reliable as Marlow himself underlines, and he is as subjugated by fascination for Kurtz as the rest of the colonists are, and just as incapable as they are of providing concrete details that justify his perception of Kurtz's greatness and depravity. Then there is the handwritten marginal note on Kurtz' report which Marlow has found: "Exterminate the brutes" (Conrad 155). Marlow reads this as the only trace of a "method" (Conrad 155), but there is no evidence (a) that the term "brutes" necessarily refers to Africans, or (b) that Kurtz himself understood this phrase as a method to be acted on. One might further object that the heads on stakes around the Inner Station, the only signs of violent action, might be taken as evidence of an attempt at extermination. Yet these too are qualified, by Marlow himself, as participating in a symbolic practice for which his Western eyes do not have the code: in the serialized version of the text, they are presented as "symbolic of some cruel and forbidden knowledge." (Conrad 214) Ian Watt points to the fact that heads on stakes participated in rites of kingship that Misri, the contemporary African ruler in Southern Congo, practiced at the time (Watt 1979, 166). This makes it less easy to consider them exclusively as the result of gratuitous acts of violence one might attribute to a madman or as participating in a project of mass extermination, though it does contribute to the interpretation that there is, in this village, someone, who may or may not be Kurtz, who has established himself as a ruler-and there are indeed historical examples of white colonists who had adopted this practice (see Conrad 214). However, the reader cannot know for sure who is responsible for these heads on stakes, and no effort is made to establish this responsibility. These then are the only details that might indicate that Kurtz has become inordinately powerful and insanely violent, and they are meagre indeed.

If the reader begins to doubt Kurtz's madness and evil violence, he or she also begins to doubt whether Kurtz is a powerful as Marlow makes out. For the figure that strikes so much terror in Marlow is presented to the reader as a frail, sick man, incapable of walking, let alone defending himself, or putting up any physical resistance to his forced repatriation. And although he is supposedly "defended" by the Africans over whom Marlow presumes he holds total, godlike sway, and who largely outnumber the European colonists on the boat, he is not capable of mobilizing them to defend himself beyond an initial, defensive volley of arrows that the colonists successfully counter. Kurtz is taken away from his supposed "kingdom" against his will, with surprisingly little resistance from those he is supposed to command. And he dies in miserable captivity, in a little dark cabin of the boat, ravaged by disease-a far from glorious end. 
What's more, his splendid oratory skills, so often vaunted by Marlow, who insists after his death that Kurtz was "a remarkable man" "because he had something to say" (Conrad 178), seem quite at odds with the relatively few, singularly unremarkable snatches of direct speech Marlow reports. Kurtz actually says little of any significance in the text. Even his famous final words-"the horror, the horror"-might disappoint the reader, primed as he or she is for hearing something incredibly eloquent, profound and persuasive. Marlow certainly believes these words to be an impressive "summing up", revealing "the appalling face of a glimpsed truth" (Conrad 179). But, faced with these two words repeated once, the reader is entitled to feel otherwise. To paraphrase T.S. Eliot's 1922 poem The Hollow Men, which begins with the epigraph "Mistah Kurtz-he dead", Kurtz goes out "not with a bang" but with a rather pathetic "whimper". Perhaps, muses the reader, Kurtz was not so extraordinarily intelligent, eloquent or powerful after all. Perhaps he was actually quite a banal, ordinary human being.

If so, then the reader begins to wonder what the real source of the terror and fascination that the figure of Kurtz commands might be. And conclude that it may be generated not by any exceptional qualities that Kurtz may possess, nor by any exceptional power that he may exercise, but by the simple fact that Kurtz has refused to return to the Company, he has chosen not to go back to Europe, but to live with the local Africans, gaining enough of their respect to find a place within their society. He seems to have learnt their language, which Marlow describes in the most depreciative terms as "incomprehensible", a "fiendish row" (Conrad 139), or "roaring chorus of articulated, rapid, breathless utterance" (Conrad 175), a series of epithets determined by ignorance mixed with fear and above all a sense of superiority. He has also adopted their customs, those "unspeakable rites" Marlow refers to vaguely but with evident disgust (Conrad 155). He has even taken on, perhaps-oh horror of horrors for defenders of racial superiority and purity-an African wife-if that indeed is the status of the mysterious African woman who is another object of Marlow's and the other colonists' fascination. What may well be at the root of the terror that strikes Marlow and the other colonists' hearts is not so much that Kurtz has become a barefaced symbol of colonial looting and will for power, but rather that Kurtz has crossed over to the other side. Indeed, Marlow seems attached to people staying in their roles: as Achebe highlights, he considers cannibals "fine fellows-in their place" (Conrad 138). ${ }^{9}$ It may be inconceivable to Marlow that Kurtz, a European colonist, might have changed sides without becoming "horrific". This might explain why Marlow clearly distinguishes the "original Kurtz", which "all Europe created", on the one hand, from the "ghost" of that person whom Marlow encounters, a "ghost" who, he specifies quite clearly, comes from "the back of Nowhere", another euphemism for a continent the text never names but is quite clearly and recognizably, Africa (Conrad 154). ${ }^{10}$ In designating Africa as "nowhere", Marlow is once again clearly caught up in the Eurocentric colonial system of representation Achebe and Saïd denounce. But the point here is that Kurtz's changing sides is the real transgression he has committed in Western colonists' eyes; these colonists who can only interpret Kurtz's refusal to return to the Europe as an incomprehensible sign of madness, the evidence that he has submitted to the siren calls of a "dark" and "obscure", "inscrutable" wilderness. ${ }^{11}$

The dissonance between Marlow's horrified description of Kurtz' degeneration and the concrete details he gives to support it is such that the text ends up highlighting the hysterical reaction of the colonists, and raises questions in the reader's mind as to the foundations of this hysteria. Marlow's tale seems to vehicle at least two fears. The first 
is miscegenation, linked to the figure of the African woman Kurtz is linked with, who seems so powerful, intimidating and bewitching to Marlow and his fellow colonists. ${ }^{12}$ The second is atavism or "inverse Darwinism". As discussed by John W. Griffith in Joseph Conrad and the Anthropological Dilemma, the late $19^{\text {th }}$ century discipline of anthropology developed the idea that contact with so-called "primitive" peoples might awaken the "savage" that lies dormant in all human beings, when the bars of civilization and social control that hold us back from our baser impulses are lifted (see also Brantlinger 2004). The echoes with Marlow's discourse concerning restraint are plain to see (see Griffith, ch. 5 and 6). So are the echoes with the aforementioned contemporary distortions of Arendt's formula concerning the banality of evil, which draw the conclusion that humanity is fundamentally monstrous, and all humans would act terribly if placed in the right context, without their "rivets" or cultural restraints. Marlow's discourse on the importance of "rivets" of restraint could indeed be seen as an anticipation of a trend within contemporary fiction that focuses on perpetrators, and its attendant assumptions concerning human nature, a fascination which poses considerable ethical problems, notably in that it releases perpetrators-here colonistsfrom a certain level of responsibility for their acts (Lacoste).

In the reading of "Heart of Darkness" I am suggesting here, then, the figure of Kurtzgone-bad might embody less the horrors of colonialism itself and more the worst nightmares of colonial powers: that its agents might "go native", a gesture that challenges the cultural and civilizational superiority of the colonizing forces. This is where I would take issue with Patrick Brantlinger, who has nonetheless developed one of the most thorough-going and rigorous anti-colonial readings of "Heart of Darkness", when he states that the worst "perversion" of critics is to "see Kurtz not as an abomination" (1996, 291). For Brantlinger continues to adhere to Kurtz's exceptionalism, considering that Kurtz represents the brute violence of the whole colonial enterprise, which means that entertaining the idea that Kurtz might not be as terrible as Marlow believes is to entertain the idea that colonialism in the Congo was also not so terrible $(1996,292)$. In questioning the interpretation of Kurtz as exceptionally bad, I am in no way suggesting that the effects of colonialism in the Congo were not exceptionally bad. On the contrary. I am arguing that being attentive to the dissonance between Marlow's discourse of terror and the concrete facts he provides to support it suggests that something other than the horrors of colonial violence in the Congo is at stake in Marlow's reaction to Kurtz. It is worth noting that not only Marlow but also the other colonists such as the Manager of the Central Station, who unthinkingly convey the structural violence of colonialism and are immediately responsible for the irrational violence, famine and exploitation of the African population and continent Marlow describes in the text ${ }^{13}$, also find Kurtz terrifying. If these characters, represented as perpetrators of both insidious structural but also obvious individual violence against Africans, see Kurtz's fate as a sign of madness, then this should give us, as contemporary readers seeking to go beyond colonial mindsets, pause.

20 It should allow us to consider another interpretative option: that racialized prejudices of cultural superiority and spurious ideals of racial purity-more than the declared horror at brute violence-may be the unacknowledged mechanisms at work in the terror which Kurtz provokes in his fascinated fellows, Marlow included. ${ }^{14}$ If Kurtz continues to be seen by them as exceptional, it is in that he has excepted himself from the colonial project, from the Western world, and its cultural structures. Which might 
make him an object not of terror but of interest for readers who attempt to situate themselves outside of the colonial mindset. We might even be brought to ask ourselves if Kurtz has actually committed anything anti-colonialists would consider an atrocity at all. That there are historical examples of European colonists "going native" in ways that involved the abuse of local populations, and that such examples may well have influenced Conrad (Conrad 214, see also Mahood 4-36), tempers such interpretative ardor. But the fact that this question might be raised is in itself revealing of the extent to which Conrad's text provides us with the tools to read it against Marlow's own vision of an abominable, fascinating Kurtz.

21 If, then, we are capable of glimpsing a Kurtz that might differ from the exceptionally bad or exceptionally powerful status Marlow projects upon him, we are able to take the critical distance necessary to ask what really makes the colonists see him as a particularly terrible, evil, and all-powerful being, and interrogate the practical and theoretical consequences of a vision which uncritically accords the colonist the potential for total power. In other words, we might begin to de-mystify the supposedly natural dominance of the colonist and bring a knock to the statue of its absolute status, which in turn might allow us to envisage sites of resistance to this power. It is doubtful that Conrad intended this reading, as his own views of colonialism, much analysed, were at best complacent. Neither am I suggesting that "Heart of Darkness" could form part of any decolonial canon. But the ambiguities Conrad's text introduces concerning the exact nature Kurtz's transgression leave the door open for a reading of "Heart of Darkness" against Marlow's-and Conrad's-fascination with the colonial enterprise, one which helps us better understand the mechanisms, fears and insecurities that inform it.

\section{RE-IgNITINg THE FASCINATION: APOCALYPSE NOW}

The dissonance between the fantasy of Kurtz's exceptional badness and the concrete details provided to support it disappears entirely in Francis Ford Coppola's screen adaptation of Conrad's tale, Apocalpyse Now (American Zoetrope, 1979). Coppola transposes Conrad's text into the context of the American war in Vietnam, where Captain Willard, the Marlow figure and voice-over narrator, is sent upriver by the army's top brass in search of the renegade General Kurtz, who has escaped from the American army's control in North Vietnam. As Willard gets closer to his destination, his interest in and attraction towards Kurtz grows stronger. But when he eventually does reach Kurtz's domain, what he finds not only confirms Central Command's description of Kurtz as having gone dangerously crazy, but surpasses his own worst nightmares.

There is no doubt in the film that Kurtz has managed to get the locals-who are reduced, once again, to exotic caricatures of savages-to worship him. Neither is there any doubt that Kurtz has gone mad-nor that, in spite of this, he is an eloquent, gifted and intelligent man, shown reading poetry, quoting liberally from T.S. Eliot's "The Hollow Men", astutely analysing the American situation in Vietnam, and capable of fine and strong feeling. There is also no doubt that he has gone bad: he kills indiscriminately in order to establish, through terror, a reign of absolute power. Incarnated on screen by the physically imposing and charismatic Marlon Brando filmed in chiaroscuro, there is nothing weak, feeble or incapable about Coppola's Kurtz. This Kurtz is quite capable of defending himself, shutting Captain Willard up in a cage, 
brutally decapitating an American soldier and tossing his head into Willard's lap, and commanding a large army of subservient and loyal locals. And when Kurtz does die in the film, it is neither from illness nor from surrender. Willard, popping a few "rivets" on the way, hacks him to pieces with a machete, an act which the film editing intersperses with the sacrifice of a buffalo, so as to elevate it to glorious, ritual status. Many critics have underlined the features of this scene that make it read as regicide (LaBrasca 291, Hagen 293). This is certainly no pitiful end like that to which Conrad's Kurtz comes. On the contrary, it is presented as a dignified way out for Kurtz: "Everyone wanted me to do it. Him most of all..." says Willard, who describes the upcoming assassination as a means of allowing Kurtz "to go out like a soldier" (Apocalypse Now, ch. 16). Coppola's Kurtz is a far cry from the disappointing, weak, deflated and defeated Kurtz of Conrad's text.

The film's magnification of Kurtz' murderous folly grants him a quasi-heroic status and plays into fantasies of total colonial power, as critics have not failed to highlight (LaBrasca 291-292, Dumoulié 298-299). Coppola delivers the spectator with a Kurtz figure typical of the exceptional "monster" figure that Arendt and Lacoste warn us against, contributing to what Lacoste describes the seductiveness of perpetrators of violence, which excuses, at least in part, the ethically reprehensible nature of their actions, and minimizes the possibility of considering their actions as those of banal, unadmirable individuals-a status which would potentially implicate more clearly the ordinary reader in the violence described, be he or she Conrad's contemporary British reader or Coppola's fellow American.

What's more, in the film's dialogue, Coppola's Kurtz suggests that if the Americans failed in Vietnam, it is because they were too squeamish and undisciplined to fully exercise the power that they nonetheless held (LaBrasca 292), corrupted as they were not only by hypocrisy but also by sex drugs and rock n' roll. The example set by Kurtz in the film proves that the Americans could have won in Vietnam if they had really wanted to, albeit at considerable ethical cost-a position that Coppola's Kurtz articulates quite clearly. While the film does not overtly sanction this position, neither does it denounce it. Rather it presents on screen, in sumptuous décor and impressive imagery, the power it suggests the Americans could have deployed, had they had less moral scruples. This power is staged both in this final scene and in the previous dawn attack on a village led by the not-so-subtly named Lieutenant Colonel Kilgore, which constitutes an aestheticized choreography of helicopters bombing the village to the music of Wagner's Ride of the Valkyries. The reader is again reminded of America's potential for destruction when, after Willard has performed the assassination, he returns to his boat to leave Kurtz's domain, and hears the US army napalm unit, appropriately named "Almighty", with its clear religious connotations of divine power, crackling over the radio. Taken together, one can understand why this film could be screened to American soldiers to galvanize them before missions to Afghanistan or Iraq (Dumoulié 298-299).

26 "Heart of Darkness" resists being used to similar ends. Unlike Coppola's film, the irony of Conrad's text, which allows for a contrast between what the narrator Marlow thinks he is showing and what the reader is actually shown, allows the novella to expose and denounce the fantasies of power that animate the colonial project, by presenting them as fantasies rather than as the exact accounts of Kurtz's reality. ${ }^{15}$ That Conrad's Kurtz might appear to the reader as an unremarkable, unexceptional individual allows us to 
detach ourselves from Marlow's fascination and begin identifying the racial prejudices and presuppositions behind what makes him terrifying to his fellow colonists, Marlow included. This is where any critique of colonization that may be found in this tale, might begin.

\section{BIBLIOGRAPHY}

Achebe, Chinua. “An Image of Africa: Racism in Conrad's 'Heart of Darkness'.” Massachusetts Review 18 (1977): 14-27.

Alvarez Calleja, Maria Antonia. “Joseph Conrad's 'Heart of Darkness' as a Journey in Quest of the Self." Odisea 4 (2003): 7-16.

Apocalypse Now, dir. Francis Ford Coppola, American Zoetrope, 1979.

Arendt, Hannah. Eichmann in Jerusalem: A Report on the Banality of Evil. New York: Viking, 1963.

Atkinson, William. "The Elephant in the Text: Toward a Post-Humanist Reading of Heart of Darkness." In Critical Approaches to Joseph Conrad. Ed. Agata Szczeszak-Brewer. Columbia, South Carolina: South Carolina University Press, 2015. 59-70.

Brantlinger, Patrick. "Victorians and Africans: The Genealogy of the Myth of the Dark Continent." In Joseph Conrad's "Heart of Darkness": A Casebook. Ed. Gene M. Moore. Oxford: Oxford University Press, 2004. 43-88.

---. “'Heart of Darkness': Anti-Imperialism, Racism, or Impressionism?” In Heart of Darkness, Joseph Conrad. Ed. Ross C. Murfin, Ross C. Murfin. Boston, New York: Saint Martin's Press, coll. Case Studies in Contemporary Criticism, 1996. 277-298.

Conrad, Joseph. Heart of Darkness [1899] and Other Tales. Oxford: Oxford World's Classics, 2002.

Dumoulié, Camille. Fureurs: De la fureur du sujet aux fureurs de l'histoire. Paris: Economica, 2012.

Eliot, T. S. “The Hollow Men”. In Poems: 1909-1925. [1925]. London: Faber \& Faber, 1942.

Griffith, John W. Joseph Conrad and the Anthropological Dilemma. Oxford: Clarendon, 1995.

Guerard, Albert J. “The Journey Within.” [1953]. In Heart of Darkness, Joseph Conrad. Ed. Robert Kimbrough. Norton Critical Edition [1963], $3^{\text {rd }}$ edition, 1988. 243-250.

Hagen, William M. "Heart of Darkness and the Process of Apocalypse Now" [1981]. In Heart of Darkness, Joseph Conrad. Ed. Robert Kimbroug. Norton Critical Edition [1963], $3^{\text {rd }}$ edition, 1988. 293-301.

Haugh, Robert F. “'Heart of Darkness': Problem for Critics” [1957]. In Heart of Darkness, Joseph Conrad. Ed. Robert Kimbrough. Norton Critical Edition [1963], $3^{\text {rd }}$ edition, 1988. 239-242.

Hawkins, Hunt and Brian W. Shaffer (eds). Approaches to teaching Conrad's "Heart of Darkness" and "The Secret Sharer". New York: MLA, 2002.

LaBrasca, Robert. “Two Visions of 'The Horror!” In Heart of Darkness, Joseph Conrad. Ed. Robert Kimbrough. Norton Critical Edition [1963], $3^{\text {rd }}$ edition, 1988. 288-293. 
Lacoste, Charlotte. Séductions du bourreau, négation des victimes. Paris: Presses Universitaires de France, 2014.

Mahood, Molly. The Colonial Encounter: A Reading of Six Novels. Rowman and Littlefield, 1977.

Miller, J. Hillis. "Heart of Darkness Revisited” (1983). In Heart of Darkness, Joseph Conrad. Ed. Ross C. Murfin. Boston, New York: Saint Martin's Press, coll. Case Studies in Contemporary Criticism, 1996. 206-220.

Paccaud-Huguet, Josiane. "Kurtz ou les vestiges du jour." In Joseph Conrad 2. Heart of Darkness, une leçon des ténèbres. Ed. Josiane Paccaud-Huguet. Paris: Lettres Modernes Minard, 2002. 159-184.

Parry, Benita. Conrad and Imperialism: Ideological Boundaries and Visionary Frontiers. Salem: Salem House, 1983.

Pedot, Richard. “'Aux limites de la vérité': l'expérience du récit dans 'Heart of Darkness'.” Études anglaises 55:3 (2002): 308-319.

---. "Heart of Darkness" de Joseph Conrad: Le Sceau de l'inhumain. Paris: Editions du temps, 2003.

Peters, John Gerard. Joseph Conrad's Critical Reception. Cambridge: Cambridge University Press, 2013.

Rechtman, Richard. La Vie ordinaire des génocidaires. Paris : CNRS éditions, 2020.

Schaffer, Brian W. “The Role of Marlow's Nellie Audience in 'Heart of Darkness'." In Approaches to teaching Conrad's "Heart of Darkness" and "The Secret Sharer". Ed. Hunt Hawkins and Brian W. Shaffer. New York: MLA, 2002. 67-73.

Saïd, Edward. Culture and Imperialism. London: Chatto and Windus, 1993.

Singh, Frances B. “The Colonialistic Bias of Heart of Darkness" [1978]. In Heart of Darkness, Joseph Conrad. Ed. Robert Kimbrough. Norton Critical Edition, $3^{\text {rd }}$ edition, 1988. 268-280.

Trilling, Lionel. "On the Modern Element in Literature." In Beyond Culture: Essays in Literature and Learning. Ed. Lionel Trilling. New York: Harcourt, 1965.

Watt, Ian. Conrad in the Nineteenth Century. Los Angeles: University of California Press, 1979.

---. “Conrad's Impressionism.” In Joseph Conrad's Heart of Darkness: A Casebook. Ed. Gene M. Moore. Oxford: OUP, 2004. 169-182.

Young, Robert J. C. Colonial Desire: Hybridity in Theory, Culture and Race. London and New York, Routledge, 1995.

\section{NOTES}

1. In La Vie ordinaire des génocidaires, Richard Rechtman's important anthropological study of societies in which a genocide has been perpetrated and of refugees from such societies, he shows that most people are "unavailable" for use in genocidal projects.

2. As the frame narrator notes in a famous passage often taken as a model for the modernist relationship to language: "to him [Marlow] the meaning of an episode [...] [envelops] the tale which brought it out only a glow brings out a haze, in the likeness of one of these misty halos that sometimes are made visible by the spectral illumination of moonshine." (Conrad 105). Marlow's "impressionism" has been analysed notably by Ian Watt (1979 169; 2002). E. M. Forster but also and most famously the critic F. R. Leavis were disparaging about the "obscure" nature of the text (cited in Haugh, 240). 
3. Indeed, the frame narrator's initial presentation of Marlow emphasizes Marlow's difference from the "best of fellows" aboard the Nellie, the lawyer, the accountant and the Director of Companies, all of whom were once participants in the colonial enterprise, and with whom he seems to situate himself unquestioningly. This is done through the use of a proper name for this character only, his mention of the fact that Marlow is the only one to still "'follo[w] the sea", his ironic orientalizing description of Marlow's posture and physical position apart from his companions, his emphasis on what makes Marlow's use of language different from that of others, and, finally, the fact that his own vision of the Thames as a glorious river of empire is roundly countered by Marlow's description in the opening pages. See Shaffer, 69.

4. “An Unreadable Report: Conrad's Heart of Darkness", ch. 9 in Reading for the Plot. Design and Intention in Narrative, Harvard University Press, 1992. See also Richard Pedot's 2002 discussion of the text as a return to the origins of humanity, morality and the truth, which prove elusive because linguistically based.

5. For a thorough history of Conrad's reception and the historical periods in which each of these readings emerged and met with success, see John Gerard Peters.

6. The motif of the circus animal in Marlow's discourse is applied across racial lines to mock the vacuities and corruption of European "civilization", which Marlow believes spoils Africans and Europeans alike. He describes the fireman aboard the pilgrim's boat as "an improved specimen; he could fire up a vertical boiler. He was there below me, and, upon my word, to look at him was as edifying as seeing a dog in a parody of breeches and a feather hat, walking on his hind legs [...] He ought to have been clapping his hands and stamping his feet on the bank, instead of which he was hard at work, a thrall to strange witchcraft, full of improving knowledge" (140). The term "improved" is clearly ironical in this passage, and comes after Marlow has previously described himself and his English listeners aboard the Nelly as, in their Western lives "performing [...] monkey tricks, [...] performing on your respective tight-ropes for - what is it? Half a crown a tumble." (137), a statement that provokes the only reproach his listeners address him in the entire narrative. Although this might suggest that the object of Marlow's critique is Western civilization in general, it does not, of course, annul the racism that is also involved in the description of the fireman, amply discussed by Achebe.

7. See the texts collected in Hawkins and Shaffer.

8. Marlow uses the term "remarkable" just as frequently as the term "exceptional" to qualify Kurtz, if not more so. The adjective (and substantive) use of the term "remarkable" is a close synonym of "exceptional" (see the OED), and Marlow's qualification of Kurtz as "remarkable" may be understood to cover an almost identical semantic field. The main differences between the two terms are (a) the foregrounding of the visual sense in "remarkable" and (b) the positive connotations that are attached to "remarkable", whereas "exceptional" is a more neutral descriptive term. The choice of the term "remarkable" therefore emphasizes the sensory register Conrad is so well-known for, as well as subtly insisting upon the attraction that Kurtz exercised on Marlow, precisely for his supposedly exceptional qualities.

9. In Achebe's analysis of the text, he cites this passage and identifies Marlow's position here with Conrad's (Achebe 18). While such an amalgamation is understandable, it seems important to distinguish between Marlow's narrative position and the meaning the text of "Heart of Darkness" projects, which surpasses and can be analysed independently of any authorial intention. I suggest here that "Heart of Darkness" provides us with the tools to read Conrad against himself, and thereby better expose the fears and insecurities that inform the colonial enterprise.

10. "Nowhere" could also be read, it has been pointed out to me, as "Now here", which resonates with the ghostly aspect of the Kurtz being described and contributes to the unheimlich aspect of the text which a number of critics (Paccaud-Huguet 163, amongst others) have drawn attention to. According to this interpretation, Kurtz the ghost of a European, is a distorting mirror of the colonial enterprise. Yet the words which precede "Nowhere"- "from the back of"-seem not only 
to encourage but to privilege a more literal reading of "Nowhere", making it difficult not to see this word primarily as a stand-in for the African continent, with all the Eurocentric suppositions that entails, whatever other interpretations psychoanalytic readings might also offer.

11. Frances B. Singh makes a similar observation, without developing the point further: “According to Marlow, Kurtz's depravity consisted of a terrible egotism which made him seek gratification for various lusts in "unlawful" ways. Those "unlawful" ways, however, seem to be nothing more than Kurtz's adoption of the customs of an African tribe. So what Marlow implies is that Kurtz's tribalization is a symbol of his depravity. From the little we see of Kurtz's followers, though, there is nothing to suggest that they are depraved. Rather they appear as protective, simple and unselfconscious-far better specimens of humanity than the white people of Heart of Darkness." (276).

12. On the question of miscegenation as both a taboo and a desire in late $19^{\text {th }}$ century British colonial discourse and practice, see Robert J. C. Young.

13. See, for example, Marlow's arrival on the continent and his trip to the Central station, which expose him directly to the folly and horrors of colonialism as practiced by the Central Station Manager and his fellows: the warship firing randomly into the jungle, the chain gang, the famished shadows of human beings, the gratuitous violence exercised on individual Africans.

14. On this question, see also "Victorians and Africans" (Brantlinger 2004). Though Brantlinger makes brief mention of Conrad's "Heart of Darkness", he does not develop the theses advanced here, which, however, concord with his more general analysis of anthropological, biological, and social evolutionist notions of race which reinforced the colonial project and were conveyed through literature at the time.

15. Coppola's film does have one moment of reflexive mise-en-abyme, suggesting a narrative layering that might be akin to the frame narration structure of "Heart of Darkness": during the scene that introduces the spectator to the not-so-subtly named Lieutenant Colonel Kilgore, we see Coppola himself filming the arrival of Willard and his crew ashore, where Coppola is seen giving them indications to move on (Apocalypse Now, ch. 4). But this brief flash of narrative distance is rapidly reduced to nothing, leaving no place for an ironic or critical take on Willard's fantasies of Kurtz's perspicacity, eloquence, and power.

\section{ABSTRACTS}

In Joseph Conrad's Heart of Darkness, Kurtz is constantly described as an exceptional figure: after excelling in the colonial enterprise in an outstanding way, he becomes its extraordinarily horrific incarnation in the eyes of the company and of the narrator Marlow, who each give expression to contemporary colonial anxieties concerning atavism and "going native". Kurtz's exceptionalism thereby gives rise to the fascination with colonialism itself that structures the text. However, Conrad undermines this fascination by inviting us to read the figure as the most banal and ordinary product of Western civilization, neither remarkable nor terrifying. This paper argues that the banalization of Kurtz is key to any critique of colonialism that might be read in this text. It then examines Francis Ford Coppola's reprisal of the figure in the 1979 film Apocalypse Now to show that by exacerbating Kurtz's exceptional nature, the film encourages fascination with the colonial enterprise and absolute power once again. 
Dans «Au Cœur des ténèbres » de Joseph Conrad, le personnage de Kurtz est sans cesse présenté comme exceptionnel. Du point de vue de la Compagnie et aussi du narrateur Marlow, il se distingue d'abord par ses talents hors du commun, qu'il met au service de l'entreprise coloniale avec une efficacité redoutable, pour ensuite devenir l'incarnation particulièrement terrible des horreurs du colonialisme. En décrivant Kurtz comme exceptionnellement doué, puis exceptionnellement mauvais, les colons et Marlow expriment les angoisses coloniales contemporaines relatives à l'atavisme et à "l'ensauvagement" des occidentaux, tout en alimentant la fascination pour l'entreprise coloniale qui informe la structure même de la nouvelle. Néanmoins, le texte de Conrad met cette fascination à mal en invitant le lecteur à douter de l'exceptionnalisme de Kurtz, à trouver en lui plutôt une expression ordinaire, voire banale, de la culture occidentale. Cette banalisation de Kurtz joue un rôle clé dans la critique du colonialisme que l'on peut lire dans ce texte. Une comparaison avec la manière dont Kurtz est présenté dans le film Apocalypse Now de Francis Ford Coppola (1979), une des adaptations les plus connues de la nouvelle de Conrad, est à ce titre instructive. En exacerbant l'exceptionnalisme de Kurtz et en supprimant le doute quant à sa puissance maléfique, le film renoue avec la fascination pour l'entreprise coloniale et les fantasmes de puissance absolue, à des fins éthiques discutables.

\section{INDEX}

Keywords: Joseph Conrad, Heart of Darkness, Francis Ford Coppola, Apocalypse Now, colonialism, fascination, exception, banality.

Mots-clés: Joseph Conrad, « Au Cœur des ténèbres », Francis Ford Coppola, Apocalypse Now, colonialisme, fascination, exception, banalité

\section{AUTHORS}

\section{NAOMI TOTH}

Maître de Conférences

Université Paris Nanterre

ntoth@parisnanterre.fr 